\title{
Bronchial responsiveness and symptoms in 5-6 year old children: a comparison of a direct and indirect challenge
}

\author{
Nicola $M$ Wilson, Peter Bridge, Michael Silverman
}

\begin{abstract}
Background - The level of bronchial responsiveness in those with definite asthma correlates with disease severity and markers of airway inflammation. However, in population studies no clear distinction between normal and abnormal is found. Since the outcome of wheeze in early childhood is very variable, a marker of underlying airway inflammation would be of practical value. A stimulus acting indirectly may be more appropriate than one acting directly on smooth muscle. In this study the airway response to a direct (methacholine) and indirect (hypertonic saline) challenge have been compared in 5-6 year old children with past or present wheeze to see if symptom patterns or severity could be distinguished by either test. Methods - Forty children with a wide spectrum of wheeze were monitored for a six month period after which their pattern and severity of symptoms were graded. Hypertonic saline and methacholine challenges were then performed on separate days. The response was assessed by both respiratory resistance $\left(\operatorname{Rrs}_{6}\right)$ and transcutaneous oxygen $\left(\mathrm{PTCO}_{2}\right)$. Atopic status was determined by IgE and skin prick tests. Results - The results of both challenges were similar whether assessed by $\operatorname{Rrs}_{6}$ or $\mathrm{PTCO}_{2}$. There was no difference in the response to either methacholine or saline between different symptom patterns or severity grades, nor was there any correlation with either test to atopic status.

Conclusions - Neither an indirect nor a direct challenge distinguished between past or present wheeze or degree of clinical severity in this group of children. Either wheezy children of this age do not have airway inflammation or bronchial responsiveness is not a marker for it.

(Thorax 1995;50:339-345)
\end{abstract}

Keywords: saline challenge, bronchial responsiveness, children.

In adults and children of school age atopic asthma is strongly related to increased bronchial responsiveness to inhaled methacholine or histamine. ${ }^{1-6} \mathrm{~A}$ clear difference in the level of bronchial responsiveness between subjects with definite asthma and normal subjects can be demonstrated. ${ }^{1}$ Moreover, in many studies the level of bronchial responsiveness in asthmatic patients has been found to correlate, not only with the need for asthma medication, but also with markers of airway inflammation such as the proportion of eosinophils in the bronchoalveolar lavage fluid and induced sputum. ${ }^{7-9}$ However, in population studies the distinction between normal and abnormal is not so clear cut and no particular level of responsiveness can be found to distinguish normal from abnormal. ${ }^{1011}$ Furthermore, bronchial responsiveness is increased in a number of respiratory conditions other than asthma. ${ }^{12}{ }^{13} \mathrm{It}$ has been claimed that the response to a stimulus such as exercise or osmotic load, acting indirectly via a neuronal pathway or via activated mast cells with subsequent release of preformed mast cell mediators, may be more indicative of airway inflammation, and thus asthma, than the response to a stimulus acting directly on smooth muscle such as histamine or methacholine. ${ }^{1415}$

It is becoming generally recognised that wheezing in early childhood is a heterogeneous condition and that most children who wheeze in the first few years of life do not go on to develop atopic asthma. ${ }^{1617}$ We reasoned that those children with episodic viral wheezy lower respiratory illness with prolonged symptom free intervals had no chronic inflammation and a good prognosis, in contrast to chronically wheezing children who had a poorer prognosis on the basis of chronic airway inflammation. This study was designed to investigate the relationship between bronchial responsiveness to both direct and indirect stimuli and symptoms, in a group of currently or previously wheezing children, with the view to rationalising the classification of wheezing in young children. Our hypothesis was that those children whose symptoms persisted to 5-6 years of age and were provoked by a number of environmental triggers, including virus infections, would have higher levels of bronchial responsiveness, perhaps reflecting underlying airway inflammation, than those who wheezed only in response to viral infections and who were symptom free between such infections or had ceased to wheeze.

\section{Methods}

SUBJECTS

Fifty seven children aged $4 \cdot 6-6 \cdot 0$ years were recruited either from the paediatric asthma clinic or from those followed up since admission to hospital with wheeze in the first two years of life. This combination of sources was chosen to include three groups: (1) those with trouble- 
some wheeze, (2) those who had outgrown their symptoms, and (3) those who were experiencing only mild episodic wheeze in relation to virus infections.

\section{PROTOCOL}

For six months before the challenge tests a monthly respiratory diary was kept for each child. This recorded the severity of any cough or wheeze and their relation to clinical viral infections, as well as medication use. Methacholine and hypertonic saline challenges were then performed in random order within seven days. Bronchodilator drugs and cromoglycate were stopped for at least 12 hours and inhaled steroids were continued normally. No child was tested within two weeks of a respiratory infection or one month of taking oral steroids. No changes had been made to prophylactic medication within three months of the study. Skin prick tests to five common allergens including house dust mite were carried out, and blood was taken for estimation of total and house dust mite specific IgE (Pharmacia Diagnostics) at one of the visits.

To calculate intrasubject repeatability of each challenge test some of the children performed either the methacholine or hypertonic saline challenge twice within seven days. The study was approved by the hospital ethics committee and parents gave written consent for their child to be included.

\section{CLINICAL GRADING}

Two methods of clinical grading (symptom pattern and symptom severity within the preceding three months) were used based on the symptom records of the six month follow up period.

\section{Symptom pattern}

The symptom pattern was classified into three patterns: (a) remission when no lower respiratory symptoms had occurred for at least six months; (b) viral wheeze when episodic wheeze was associated with clinical viral infections only; and (c) multiple wheeze when wheeze occurred at times other than in the presence of virus infections; most also experienced wheezing related to virus infections.

\section{Symptom severity within the preceding three months}

This was also classified into three groups: (a) nil, when no symptoms had occurred for at least three months and no treatment was taken; (b) mild, without hospital admission or oral steroids and bronchodilator use on average less than three days per week in the absence of viral infections; and (c) severe, if a severe attack with a viral infection had occurred necessitating use of oral steroids or hospital admission, nights disturbed more than twice weekly, or exercise induced or nocturnal symptoms resulted in bronchodilator use more than an average of three days per week, in the absence of viral infections.

\section{ATOPIC STATUS}

Presence of atopy was defined as a weal diameter of $\geqslant 3 \mathrm{~mm}$ greater than the negative control to one or more allergen. A RAST score of 1 or more to house dust mite or a positive skin prick test was taken as evidence of sensitisation to house dust mite.

\section{ASSESSMENT OF RESPONSE TO CHALLENGE}

Two methods were used.

(a) The measurement of respiratory resistance at $6 \mathrm{~Hz}\left(\mathrm{Rrs}_{6}\right)$ employing the forced oscillation technique using a machine designed and made by Landser. ${ }^{18}$ The child sat with nose clipped and cheeks supported, breathing quietly through a mouthpiece. Only values with a coherence (signal:noise ratio) of $\geqslant 95 \%$ were accepted. The baseline value was taken as the mean of six values. Three minutes after each or inhalation the measurement was repeated three times. The first coherent value was taken as the post challenge value.

(b) Transcutaneous oxygen $\left(\mathrm{PTCO}_{2}\right)$ was meas- 은 ured with an electrode (Cutan $\mathrm{Po}_{2}$ monitor, $\overrightarrow{7}$ Kontron, USA) attached to the anterior chest wall. The mean of eight values, recorded at precisely one minute intervals, was taken as the $\vec{\theta}$ baseline value. After each step the $\mathrm{PTCO}_{2} 2-3$ o minutes after inhalation, immediately before $\mathrm{Rrs}_{6}$ measurements, was accepted.

Inhalation of methacholine and saline continued until one of the following occurred: the

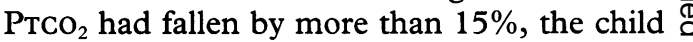
was distressed, or the maximum dose had been reached.

\section{METHACHOLINE CHALLENGE}

Methacholine chloride $(0 \cdot 5-32 \mathrm{~g} / \mathrm{l})$ (Sigma Chemicals, USA) was inhaled through a mouthpiece connected to a Wright nebuliser for one minute periods. The concentrations were increased in quadrupling increments until the $\mathrm{PTCO}_{2}$ had fallen by approximately $1 \mathrm{kPa}$ $(10 \%)$ when doubling concentration increases were used.

\section{HYPERTONIC SALINE CHALLENGE}

Saline $(4.5 \%)$ aerosol generated from an ultra- స్ sonic nebuliser (Mistogen, Equip Co, Lancaster, USA) was inhaled through a wide bore valve (No. 2700 Hans Rudolph Inc, Kansas City, USA) for doubling periods of 0.5 minutes to 8 minutes. To calculate the delivered dose for each inhalation period the nebuliser and tubing were weighed before and after each $\stackrel{\odot}{\mathbb{}}$ completed test, and the mean rate of nebulisate $\Omega$ delivered was calculated. From this the dose at each step was calculated. This was necessary 8 as the nebulisation rate varied between individual subjects.

\section{ANALYSIS OF RESULTS}

The concentration of methacholine $(M)$ and the dose of saline $(\mathrm{S})$ causing a $35 \%$ rise in $\mathrm{Rrs}_{6}\left(\mathrm{PC}_{35} \mathrm{M}\right.$ and $\left.\mathrm{PD}_{35} \mathrm{~S}\right)$ and a $15 \%$ fall in $\mathrm{PTCO}_{2}$ $\left(\mathrm{PC}_{15} \mathrm{M}\right.$ and $\left.\mathrm{PD}_{15} \mathrm{~S}\right)$ were calculated from 


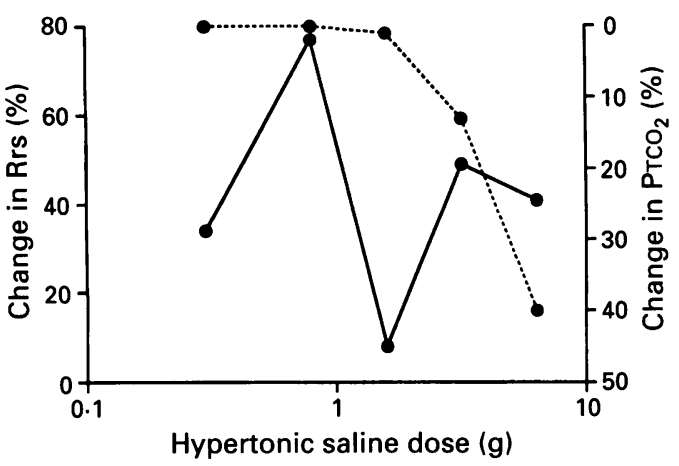

Figure 1 Result of challenge with saline in one subject illustrating the variable dose-response relationship for Rrs (solid line) and the consistent change in $\mathrm{PTCO}_{2}$ (dotted line).

the log dose-response curves. Statistical analysis was performed on log transformed data; since conditions of normality for analysis of variance were not met the Kruskall-Wallis test was used to make comparisons between groups. Negative test results were assigned values one step above the maximum used during the challenges - that is, $16 \mathrm{ml}$ for saline and $64 \mathrm{~g} / \mathrm{l}$ for methacholine - to avoid censored data, except in the repeatability study when a value of PC/ PD was obtained by continuing extrapolation of the dose-response curve if one of the pairs of tests was negative.

To compare the degree of response to methacholine and saline the results of each challenge were graded. For saline, $\mathrm{PD}_{15} \geqslant 16 \mathrm{ml}=$ grade 0 ; $3-16 \mathrm{ml}=$ grade $1 ;<3 \mathrm{ml}=$ grade 2 . For methacholine, $\mathrm{PC}_{15}>8 \mathrm{~g} / \mathrm{l}=$ grade $0 ; 3-8 \mathrm{~g} / \mathrm{l}=1$; $<3 \mathrm{~g} / \mathrm{l}=$ grade 2 . The system of grading was chosen to give a similar distribution of grades of response for each type of challenge. Comparisons of grades in the different categories was made by the $\chi^{2}$ test and $\chi^{2}$ test for trend, as were other proportional comparisons between different groups. Analysis of variance (including linear trend) was used to compare mean differences in baseline $\mathrm{Rrs}_{6}$ between groups and for the group as a whole on different days.

A $p$ value of $<0.05$ was considered statistically significant.

\section{Results}

Forty children completed the comparison of the methacholine and saline challenges satisfactorily. Two children were unable to complete the study because of uncontrollable saline-induced coughing, and three refused to return for the second study day having performed the saline challenge on the first. Seventeen children performed the repeatability study. The results of two were excluded as their

Table 1 Repeatability of saline and methacholine challenges: the single determination $95 \%$ range for change in provocative dose (PD) and provocative concentration (PC)

\begin{tabular}{|c|c|c|c|c|}
\hline & \multicolumn{2}{|c|}{ Methacholine } & \multicolumn{2}{|c|}{ Saline } \\
\hline & $R r s_{6}$ & $\mathrm{PTCO}_{2}$ & $R r s_{6}$ & $\mathrm{PTCO}_{2}$ \\
\hline $\begin{array}{l}\text { No. } \\
\text { Single determination } 95 \% \text { range for change } \\
\text { (doubling dilutions/doses) }\end{array}$ & $\begin{array}{l}7 \dagger \\
2 \cdot 9\end{array}$ & $\begin{array}{l}7 \dagger \\
2 \cdot 1\end{array}$ & $\begin{array}{l}7^{*} \\
2 \cdot 1\end{array}$ & $\begin{array}{l}8 \\
1 \cdot 4\end{array}$ \\
\hline
\end{tabular}

* One child could not cooperate with $\mathrm{Rrs}_{6}$ during one study.

t Results on one of the studies were obtained by extrapolation beyond the maximum dose in one child for $\mathrm{PTCO}_{2}$ and two children for Rrs

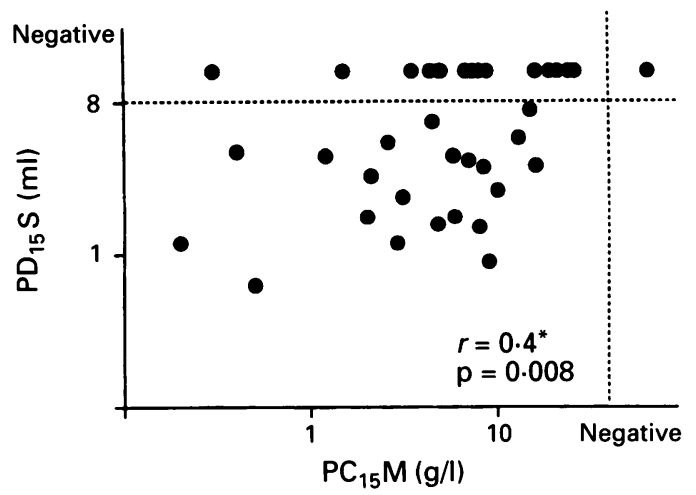

Figure 2 Comparison of individual results of challenge with methacholine (M) and saline (S) for the group as a whole. Negative responses are separated by the dotted lines. ${ }^{*}$ For negative results in saline and methacholine, $P D_{15} S 16 \mathrm{ml}$ and $P C_{15} M 64 \mathrm{~g} / \mathrm{l}$ are used.

baseline $\mathrm{Rrs}_{6}$ was over $200 \%$ predicted on one of the days. Five children took part in both the challenge comparison and one of the repeatability studies.

COMPARISON BETWEEN $\mathrm{Rrs}_{6}$ AND $\mathrm{PTCO}_{2}$ TO ASSESS RESPONSE TO CHALLENGE

For each type of challenge the results were similar whether assessed by change in $\mathrm{Rrs}_{6}$ or $\mathrm{PTCO}_{2}$. There was a significant correlation between both $\mathrm{PC}_{35} \mathrm{M} \quad\left(\mathrm{Rrs}_{6}\right)$ and $\mathrm{PC}_{15} \mathrm{M}$ $\left(\mathrm{PTCO}_{2}\right)$ and between $\mathrm{PD}_{35} \mathrm{~S}\left(\mathrm{Rrs}_{6}\right)$ and $\mathrm{PD}_{15} \mathrm{~S}$ $\left(\mathrm{PrCO}_{2}\right) \quad(r=0.35, \mathrm{p}=0.03$ and $r=0.59$, $\mathrm{p}<0.001$, respectively). There was no significant difference in mean values of $\mathrm{PC} / \mathrm{PD}_{35}$ and $\mathrm{PC} / \mathrm{PD}_{15}$ during either methacholine or saline challenge, nor did the relationships between methacholine and saline responsiveness and clinical criteria differ whether the challenge was assessed by $\mathrm{Rrs}_{6}$ or $\mathrm{PTCO}_{2}$. However, it was often difficult to calculate with confidence the $\mathrm{PC}_{35}$ or $\mathrm{PD}_{35}$ by interpolation as the change in $\mathrm{Rrs}_{6}$ sometimes showed an erratic doseresponse relationship with increasing concentrations of agonist (fig 1). The results of methacholine and saline challenges will therefore be presented using only the $\mathrm{PTCO}_{2}$ results.

WITHIN SUBJECT REPEATABILITY

Eight children performed the saline challenge and seven the methacholine challenge on two occasions. The single determination $95 \%$ range for change in PD and PC for methacholine and saline are shown in table 1 . One child could not cooperate with $\mathrm{Rrs}_{6}$ measurement during one of the saline challenges so only results with $\mathrm{PTCO}_{2}$ have been included.

\section{OVERALL COMPARISON BETWEEN}

\section{METHACHOLINE AND SALINE CHALLENGE}

There was no significant difference in baseline $\mathrm{Rrs}_{6}$ and $\mathrm{PTCO}_{2}$ between the two study days [mean (SD) Rrs $_{6}$ : 102 (24); 102 (18); mean (SD) $\left.\mathrm{PTCO}_{2}: 10 \cdot 3(1 \cdot 5) ; 10 \cdot 4(1 \cdot 4)\right]$. Eighteen children had totally negative challenge results to saline and two to methacholine. For the group as a whole there was a significant correlation between the two (fig 2). To take ac- 
Table 2 Comparison of results of methacholine and saline challenges

\begin{tabular}{lllll}
\hline & $\begin{array}{l}\text { Both negative } \\
\text { (grade 0) }\end{array}$ & $\begin{array}{l}\text { Both positive } \\
\text { (grade 1 or 2) }\end{array}$ & $\begin{array}{l}\text { Saline only positive } \\
\text { (grade 1 or 2) }\end{array}$ & $\begin{array}{l}\text { Methacholine only positive } \\
\text { (grade 1 or 2) }\end{array}$ \\
\hline $\begin{array}{l}\text { No. } \\
(\%)\end{array}$ & 10 & 14 & 7 & 9 \\
Atopic & $(25)$ & $(18)$ & $(18)$ & $(22)$ \\
$\begin{array}{l}\text { No. } \\
(\%)\end{array}$ & 7 & 4 & & 4 \\
\hline
\end{tabular}

Concordance $=60 \%$.

count of the fact that the maximum stimulus for saline may have been less than that for methacholine, arbitrary cut off points were used to define responders - that is, grades 1 and 2. By these criteria the concordance between responders and non-responders to methacholine and saline was $60 \%$ (not statistically significant); 21 responded to saline and 23 to methacholine, seven children responded only to saline and nine only to methacholine (table 2).
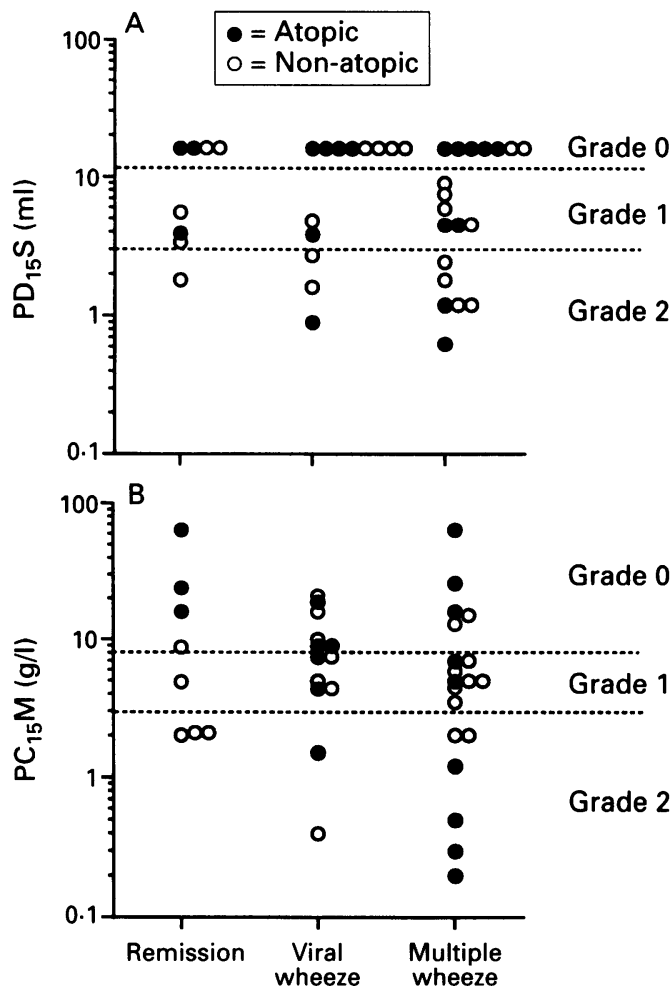

Figure 3 Individual values of $P C_{15} M$ and $P D_{15} S$ grouped according to symptom pattern. Grading of responses indicated by dotted line.
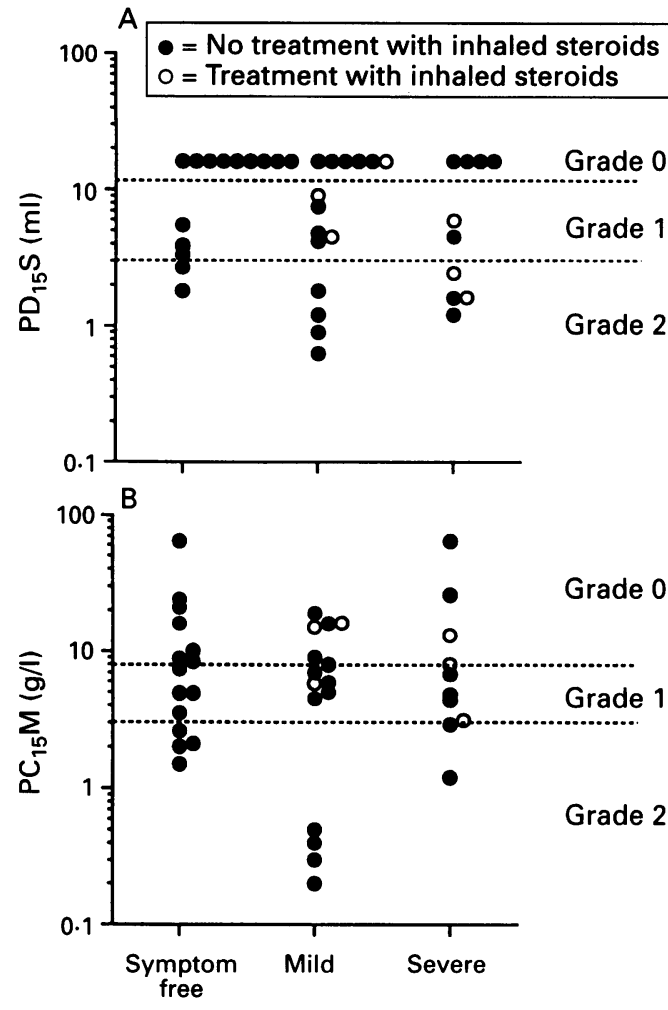

Figure 4 Individual values of $P C_{15} M$ and $P D_{15} S$ according to symptom severity. Grading of responses indicated by dotted line.

COMPARISON BETWEEN CHALLENGE RESULTS AND CLINICAL GROUPS

The only significant difference in baseline $\operatorname{Rrs}_{6} \stackrel{\vec{\circ}}{\vec{\partial}}$ and clinical groups was between those with no symptoms and those with severe symptoms in the preceding three months on the day of the saline challenge (table 3). There was, however, a significant trend towards increased values between those with no symptoms and the symptomatic groups (table 3). In contrast, there was no significant difference in median $\mathrm{PC}_{15} \mathrm{M}$ or $\delta$ $\mathrm{PD}_{15} \mathrm{~S}$ between the different clinical groups, whether categorised according to pattern of $\frac{\text { S }}{3}$ symptoms or severity of symptoms in the pre- $\rightarrow$ ceding three months (table 3 ). Although twice as many children who had been symptom free $N$ in the preceding three months did not respond to saline challenge compared with those with any symptoms, this did not reach statistical

Table 3 Results of methacholine and saline challenges according to clinical groups

\begin{tabular}{|c|c|c|c|c|c|c|}
\hline & \multicolumn{3}{|c|}{ Symptom pattern (preceding 6 months) } & \multicolumn{3}{|c|}{ Symptom severity (preceding 3 months) } \\
\hline & Remission & Viral wheeze & Multiple wheeze & Nil & Mild & Severe \\
\hline No. & 8 & 13 & 19 & 16 & 14 & 10 \\
\hline $\begin{array}{l}\text { Saline challenge } \\
\text { Mean (SD) baseline Rrs } 6 \\
\text { (\%pred) }\end{array}$ & $91(18)$ & $102(16)$ & $106(29)$ & $96(19)$ & $104(24)$ & $108(29)$ \\
\hline Median $\mathrm{PD}_{15} \mathrm{~S}(\mathrm{ml}) \dagger$ & $9 \cdot 3$ & 16 & $6 \cdot 0$ & 16 & $5 \cdot 9$ & $5 \cdot 1$ \\
\hline $\begin{array}{l}\text { Methacholine challenge } \\
\text { Mean (SD) baseline Rrs } \\
\text { (\%pred) }\end{array}$ & $91(18)$ & $\mathrm{C}^{*}(11)^{\Gamma}$ & $106(20)$ & $95(17)$ & $102(21)$ & $110(13)$ \\
\hline Median $\mathrm{PC}_{15} \mathrm{M}(\mathrm{g} / \mathrm{l}) \dagger$ & $6 \cdot 6$ & $7 \cdot 9$ & $5 \cdot 7$ & $6 \cdot 0$ & $6 \cdot 5$ & $5 \cdot 8$ \\
\hline Atopy (\%) & 38 & 46 & 47 & 38 & 57 & 40 \\
\hline $\begin{array}{l}\text { Prophylactic treatment } \\
\text { Cromoglycate n (\%) } \\
\text { Inhaled steroids n }(\%)\end{array}$ & $\begin{array}{l}0 \\
0\end{array}$ & $\begin{array}{l}0 \\
0\end{array}$ & $\begin{array}{l}5(26) \\
6(32)\end{array}$ & $\begin{array}{l}0 \\
0\end{array}$ & $\begin{array}{l}4(29) \\
3(21)\end{array}$ & $\begin{array}{l}1(10) \\
3(33)\end{array}$ \\
\hline
\end{tabular}

† For negative results $16 \mathrm{ml}$ used for saline and $64 \mathrm{~g} / \mathrm{l}$ for methacholine.

$* \mathrm{p}<0.05,{ }^{* * *} \mathrm{p}<0.01$ (analysis of variance linear trend)

$\mathrm{p}<0.05, *{ }^{*} \mathrm{p}<0.01$ (analys
t† $\mathrm{p}=0.02$ (paired $t$ test).

tt $\mathrm{p}=0 \cdot 02$ (paired $t$ test).
All other differences not statistically significant. 
significance $(95 \%$ confidence interval for the difference in proportions of negative:positive response -0.06 to 0.56 ). Grading the positive responses did not further distinguish the clinical groups or identify the more symptomatic children (fig 3 and 4).

\section{ATOPIC STATUS}

Forty five percent of all the children had one or more positive skin prick tests and $45 \%$ of them had evidence of house dust mite sensitisation by either skin prick test or IgE specific RAST. Atopic status expressed either by skin test positivity, house dust mite sensitisation, or total serum $\mathrm{IgE}$ did not relate to any index of methacholine or saline responsiveness (fig 3, table 2), nor was there any significant association between atopic status and the clinical pattern or severity.

\section{Discussion}

In this group of 5-6 year old children with past or present wheeze we were unable to show a clear association between bronchial responsiveness to either methacholine or saline and symptom pattern, symptom severity, or atopic status. Whether this result can simply be interpreted as showing that chronic inflammation is not a feature of ongoing wheeze (asthma) at this age is conjectural. The results are certainly different from what could be expected in older subjects. A comparison of bronchial response to a directly and an indirectly acting stimulus in such young children has, to our knowledge, not previously been reported.

The children were able to cooperate well with the administration of aerosol, but the assessment of the airway response to challenge is not without difficulty in this age group, since lung function tests employing repeated maximal respiratory manoeuvres cannot be performed reliably. We chose two methods of assessment that have been recommended for use in this age group but neither is without its drawbacks. ${ }^{19-22}$ Although respiratory resistance using the forced oscillation technique has been recommended for use in children as young as two years, ${ }^{19}$ it is clear that in young children it is not always reliable in the presence of induced bronchoconstriction due, probably, to a combination of an increase in resting lung volume changes and an increase in the relative contribution of upper airway compliance. ${ }^{20}$ Indeed, in this study there were occasional instances when considerable falls in $\mathrm{PTCO}_{2}$ after challenge were not associated with any increase in $\mathrm{Rrs}_{6}$. The $\mathrm{PTCO}_{2}$, on the other hand, is only an indirect indicator of induced airway narrowing resulting from $\dot{\mathrm{V}} / \dot{\mathrm{Q}}$ mismatch. It has been shown to reflect bronchoconstriction reliably during methacholine challenge in asthmatic children and normal adults. ${ }^{21-23}$ Occasionally, however, $\mathrm{PTCO}_{2}$ may increase after vigorous coughing during bronchoconstriction (personal observation), a situation not uncommon during hypertonic saline inhalation. In this study the results of both types of challenge were equivalent whether assessed by $\mathrm{Rrs}_{6}$ or $\mathrm{PTCO}_{2}$. Re- peatability was better using $\mathrm{PTCO}_{2}$ and was found to be in the range reported for older children using the gold standard lung function measure of $\mathrm{FEV}_{1}{ }^{2324}$

Only just over half (21 of 40) of the children responded to hypertonic saline challenge compared with 38 of $40(95 \%)$ to methacholine. The response rate to a particular type of challenge depends on a number of factors including those determining the lung dose of the stimulus, the arbitrary level of change in lung function chosen, as well as the underlying mechanism. The low delivered volume of saline in this study (mean (SD) $0.9(0.18) \mathrm{ml} / \mathrm{min}$ ) is probably explained by the small tidal volumes of the young children ${ }^{25}$ and in practice "size corrects" the saline dose. It is impossible to know whether the higher response rate to methacholine reflects differences in an underlying pathophysiology or a relatively larger inhaled stimulus. When the responses were graded to take into account the latter possibility, the concordance was only $60 \%$. As has also been shown in other comparisons of direct and indirect challenges in population studies of older children, ${ }^{26}{ }^{27}$ different children were often identified by the two types of tests suggesting identification of different pathological processes.

The purpose of the study was to see if it was possible to identify differences in airway pathology, to account for the very variable clinical course of young wheezers, by using the response to methacholine or saline as a possible marker for a particular underlying pathological process such as airway inflammation. Neither test identified a particular clinical group. It is possible that the relatively small numbers in each clinical group could be a factor in this lack of correlation. The overlap in the results (figs 3 and 4), however, was so great that a type 2 error of a difference of a size of any practical importance is unlikely. The only result suggestive of a difference was in the number with a negative response to saline challenge in those with no symptoms in the preceding three months compared with those with any symptoms (table 3, fig 4). To show a difference with $80 \%$ power at the $5 \%$ level between these two groups, however, a sample size of 110 children would be needed. This suggests that saline challenge has little clinical relevance as a discriminating factor in children of this age group.

Another possible explanation for these negative findings is the known modulating effect of inhaled steroids taken by six children; three of them had grade 0 response to methacholine and one to saline (fig 4). However, since $50 \%$ of the remission group showed a grade 1 or 2 response to both saline and methacholine (fig 3 ), the lack of correlation between responsiveness and symptoms cannot altogether be attributed to the use of inhaled steroids. Furthermore, in adults a need for inhaled steroid treatment was associated with greater levels of responsiveness. ${ }^{2}$

There is no agreed classification of wheezing symptoms in young children. It is clear that many children who wheeze in the first two years of life do not go on to develop atopic asthma in later childhood. ${ }^{16}$ Many stop wheez- 
ing in the preschool years while some continue to wheeze episodically in response to virus infections only. In contrast, others exhibit wheezing associated with a number of environmental triggers as well as infections from an early age, a pattern characteristic of older children with asthma. Our group of children is a good example of the diagnostic dilemma. Eleven of the children were taking continuous asthma prophylaxis because of troublesome nocturnal and exercise-induced symptoms with and without viral infections and could fairly certainly be said to justify a diagnosis of asthma. Eight further children wheezed in response to environmental triggers in addition to virus infections but were not taking continuous therapy and perhaps also merited the diagnosis of asthma. Eight other children had had no symptoms for at least six months and most for over a year and could reasonably be considered to represent a group who had grown out of recurrent infantile wheeze. ${ }^{16}$ The remainder all exhibited wheezing in response to clinical virus infections, some experiencing frequent mild symptoms and others severe but infrequent attacks. These different types of wheezers were not differentiated by their response to challenge.

In adults and older children with atopic asthma a correlation has been shown between airway inflammation, as seen by both bronchial biopsy and bronchoalveolar lavage, and bronchial responsiveness to histamine or methacholine ${ }^{78}$ in most, but not all, studies. ${ }^{28}$ Since hypertonic saline, unlike methacholine, does not act as a bronchoconstrictor agent by acting directly on smooth muscle but through mediators released from activated mast cells or via a neurogenic pathway involving release of sensory neuropeptides, ${ }^{29}$ it has been suggested that it reflects underlying airway inflammation more specifically. ${ }^{2930}$ In this study neither methacholine nor saline identified children who were likely candidates for airway inflammation, either on the basis of their pattern or severity of their symptoms or their atopic status. This suggests that either 5-6 year old children with asthma-like symptoms do not have chronic airway inflammation or that saline responsiveness is not a marker for it at this age. It is possible, however, that these children with past or current history of wheezing are to some extent hyperresponsive, but no information about bronchial responsiveness to either methacholine or saline challenge in the general population is available.

These findings are not altogether surprising when the reported relation of bronchial responsiveness to symptoms at different ages is considered. In recurrently wheezing infants no relation between the results of a direct challenge (histamine or methacholine) and symptoms has been found. ${ }^{31}{ }^{32}$ Similarly, two studies of preschool children failed to find a correlation between the level of methacholine responsiveness and severity of symptoms at three years and 4-6 years. ${ }^{334}$ When the latter study was repeated after 2-3 years children whose asthma had worsened and those with the most severe symptoms showed significantly higher levels of responsiveness, in keeping with the finding in older children. This suggests that the relation of methacholine or histamine responsiveness to symptoms changes around the age of seven years. The link could well be atopy since up to the age of seven the prevalence of both wheeze and hyperresponsiveness is similar in atopic and non-atopic subjects, whereas from seven years both decline in non-atopic children. ${ }^{3536}$ Thereafter asthma and responsiveness are strongly related to atopy. ${ }^{1637}$ A wide range in the level of bronchial responsiveness to histamine has been reported in infants which relates to a family history of asthma and smoking but not to markers of allergy or symptoms. ${ }^{38}$ It would therefore ap- . pear, from a number of observations, that the pathogenesis of bronchial responsiveness to both a direct and indirect stimulus and its $\vec{x}$ relation to symptoms in young children is or different from that in older children. A lack of relation to atopic status by 5-6 years possibly suggests that prolonged sensitisation with 6 aeroallergens is necessary before atopic airway inflammation develops.

The results of this study lead us to conclude that neither the response to a direct nor an indirect challenge relates to the pattern or severity of symptoms in 5-6 year old children with active wheeze or a past history of wheeze. Neither challenge test would be useful as a screening test for asthma, however defined, in this age group. Investigations to determine the contribution of chronic airway inflammation to wheezing in preschool children await more direct means of detection than bronchial challenge.

We thank Dr Stephen Phagoo for his help in the early stage of this work. The project was support by a grant from the National Asthma Campaign.

1 Cockcroft DW, Killan DN, Mellon JJA, Hargreave FE. Bronchial reactivity to inhaled histamine: a method and clinical survey. Clin Allergy 1977;7:235-43.

2 Juniper EF, Frith PA, Hargreave FE. Airway responsiveness to histamine and methacholine: relationship to minimum treatment to control symptoms of asthma. Thorax 1981; 36:575-9.

3 Avital A, Noviski N, Bar-Yishay E, Springer C, Godfrey $S$. Nonspecific bronchial reactivity in asthmatic children $N$ depends on severity but not age. Am Rev Respir Dis 1991; 144:36-8.

4 Joseph LK, Gregg I, Mulle MA, Holgate ST. Nonspecific ? bronchial reactivity and its relationship to clinical ex- N pression of asthma: a longitudinal study. Am Rev Respir Dis $1989 ; 140: 350-7$.

5 Salome CM, Peat JK, Britton WJ, Woolcock AJ. Bronchial hyperresponsiveness in two populations of Australian hyperresponsiveness in two populations of Australian schoolchildren. I Relation to respiratory symp

6 Pin I, Radford S, Kolendowicz R, Jennings B, Denburg JA, Hargreave FE, et al. Airway inflammation in symptomatic and asymptomatic children with methacholine hyperresponsiveness. Eur Respir f 1993;6:1249-56.

7 Ferguson AC, Whitelaw M, Brown $\mathrm{H}$. Correlation of bronchial eosinophil and mast cell activation with bronchial hyperresponsiveness in children with asthma. F Allergy Clin Immunol 1992;90:609-13.

8 Kelly C, Ward C, Stenton CS, et al. Number and activity of inflammatory cells in bronchoalveolar lavage fluid in asthma and relation to airway responsiveness. Thorax 1988;43:684-92.

W/ardlaw AJ, Dunnette S, Gleich GJ, O'Byrne PM. Bronchoalveolar cell profiles of asthmatic and nonasthmatic choalveolar cell profiles of asthmatic and non
subjects. Am Rev Respir Dis 1987;136:379-83.

10 Rijcken B, Schouten JP, Weiss ST, Meinesz AF, de Vries $\mathrm{K}$, van der Harte $\mathrm{R}$. The distribution of bronchial responsiveness to histamine in symptomatic and asymptomatic subjects. Am Rev Respir Dis 1989;140:615-23.

11 Pattemore PK, Asher MI, Harrison AC, Mitchell EA, Ree HH, Stewart AW. The interrelationship among bronchial hyperresponsiveness, the diagnosis of asthma and asthma symptoms. Am Rev Respir Dis 1990;142:549-54. 
12 Price JF, Walker PH, Harper SA, Matthew DJ. Response to bronchial provocation and exercise in children with cystic fibrosis. Clin Allergy 1989;9:563-70.

13 Britton J, Tattersfield AE. Does measurement of bronchial hyperreactivity help in clinical diagnosis of asthma? Eur hyperreactivity help in clin
Respir $₹ 1986 ; 68: 233-8$.

14 Godfrey S, Springer C, Noviski N, Maayan C, Avital A. Exercise but not methacholine differentiates asthma from chronic lung disease in children. Thorax 1991;46:488-92.

15 Pauwells R, Joos G, van der Straeten M. Bronchial responsiveness is not bronchial responsiveness is not asthma. Clin Allergy 1988;8:317-21.

16 Sporik R, Holgate ST, Cogswell JJ. Natural history of asthma in childhood - a birth cohort study. Arch Dis Child 1991; 66:1050-3.

17 Park ES, Golding J, Carswell F, Stewart-Brown S. Preschool wheezing and prognosis at 10. Arch Dis Child 1986;61: $642-6$.

18 Landser FF, Nagels J, Demedts M, Billet L, van de Woestigne KP. A new method to determine frequency characteristics of the respiratory system. F Appl Physiol 1976; 41:101-6.

19 Duiverman EJ, Neijens HJ, Van Strik R, Van Der Snee-Van Smaalen M, Kerrebijn KF. Bronchial responsiveness in asthmatic children aged 3-8 years by forced pseudorandom noise oscillometry. Bull Eur Physiopathol Respir random noise osci

20 Wilson NM, Bridge P, Phagoo SB, Silverman M. The measurement of methacholine responsiveness in 5 year old children: three methods compared. Eur Respir $\mathcal{F} 1995$ (in press).

21 Mochizuki H, Mitsuhashi M, Tokuyama K, Tajima K, Morihawa A, Kurome T, et al. A new method for measuring bronchial hyperresponsiveness in younger children. Ann Allergy 1985;55:162-6.

22 Wilson NM, Phagoo SB, Silverman M. The use of transcutaneous oxygen tension and pulse oximetry in the assessment of the response to inhaled methacholine. Thorax 1991;466:433-7.

23 Phagoo SB, Wilson NM, Silverman M. Repeatability of methacholine challenge in asthmatic children measured by change in transcutaneous oxygen tension. Thorax 1992; 47:804-8.

24 Sears MR, Jonas DT, Holday MD, Hewitt CJ, Flannery EM, Herloison GP, Silva PA. Prevalence of bronchial reactivity to inhaled methacholine in New Zealand children. Thorax 1986;41:283-9.

25 Finnerty JP, Wilmot C, Holgate ST. Inhibition of hypertonic saline-induced bronchoconstriction by terfenadine and saline-induced bronchoconstriction by terfenadine and
flurbiprofen: evidence for predominant role of histamine. Am Rev Respir Dis 1989;140:593-7.
26 Bhagat RG, Grunstein M. Comparison of responsiveness to methacholine, histamine and exercise in subgroups of asthmatic children. Am Rev Respir Dis 1984;129:221-4.

27 Haby MM, Anderson SD, Peat JK, Mellis CM, Tocke BG, Woolcock AJ. An exercise challenge protocol for epidemiological studies of asthma in children: comparison with histamine challenge. Eur Respir f 1994;7:43-5.

28 Djukovanovic R, Wilson JW, Britten KM, Wilson SJ, Walls AJ, Roche WR, et al. Quantitation of mast cells and eosinophils in the bronchial mucosa of symptomatic atopic asthmatics and healthy control subjects using immunohistocytochemistry. Am Rev Respir Dis 1990;142. 863-71.

29 Anderson SD. Asthma provoked by exercise, hyperventilation and the inhalation of non-isotonic aerosols. In: Barnes PJ, Rodger I, Thomson NC, eds. Asthma: basic mechanisms and clinical management. London: Academic mechanisms and clinical

30 Joos GF, Kips JC, Pauwells RA. Direct and indirect bronchial responsiveness. Respir Med 1993;87(Suppl):31-6.

31 Stick SM, Arnoll J, Turner DJ, Young S, Landau LI, L Souef PN. Bronchial responsiveness and lung function in recurrently wheezy infants. Am Rev Respir Dis 1991;144: 1012-5.

32 Clarke JR, Reese A, Silverman M. Bronchial responsiveness and lung function in infants with lower respiratory tract illness over the first 6 months of life. Arch Dis Child 1992; 67:1454-8.

33 Wilson NM, Phagoo SB, Silverman M. Atopy, bronchial responsiveness and symptoms in wheezy 3 year olds. Arch Dis Child 1992;67:492-5.

34 Adachi Y, Murakami G, Matsuno M, Adachi YS, Kayahara $\mathrm{M}$, Okada $\mathrm{T}$, et al. Longitudinal study of bronchial hyperreactivity in preschool children with bronchial asthma. Ann Allergy 1992;68:261-6.

35 Crane J, O'Donnell TV, Prior IA, Waste DA. The relationships between atopy, bronchial hyperresponsiveness and a family history of asthma: a cross-sectional study of and a family history of asthma: a cross-sectional study of migrant Tolkelauan children in

36 Burr ML, Limb ES, Maguire MJ, Amarah L, Eldridge BA, Layzell JC, et al. Infant feeding, wheezing and allergy: prospective study. Arch Dis Child 1993;68:724-8.

37 Sears MR, Burrows B, Herbison GP, Holdway MD, Flannery EM. Atopy in childhood III. Relationship with pulmonary function and airway responsiveness. Clin Exp Allergy 1993;23:957-63.

38 Young S, Le Souef PN, Geelhoed GC, Stick SM, Turner KS, Landau LI. The influence of a family history of asthma and parental smoking on airway responsi 